\title{
PARTISIPASI MASYARAKAT DALAM PROSES KEBIJAKAN
}

\author{
Dede Mariana \\ e-mail: dedemariana@yahoo.com
}

\begin{abstract}
ABSTRAK
Teori kebijakan era tahun 60-an lebih memandang proses kebijakan dari perspektif administrasi publik. Proses kebijakan dipandang linear dan mekanistik. Sementara, partisipasi masyarakat hanya dipandang sebagai formalitas bagi legitimasi kebijakan. Selama ini, partisipasi cenderung dimaknai secara kuantitatif (hanya dihitung dari jumlah partisipan atau jumlah organisasi masyarakat yang dilibatkan). Padahal, proses kebijakan akan jauh lebih bermakna sebagai proses demokrasi manakala partisipasi diperluas sebagai kesempatan bagi seluruh warga masyarakat untuk menyampaikan aspirasinya secara argumentatif. Artikel ini menjelaskan bagaimana pemberdayaan masyarakat dapat dilakukan untuk berpartisipasi dalam pembuatan kebijakan, yakni melalui pendekatan struktural dengan mengadvokasikan berbagai instrumen hukum dan kelembagaan yang memberi peluang bagi masyarakat untuk berpartisipasi dan pendekatan sosiokultural melalui proses pendidikan, pengorganisasian, dan pendampingan masyarakat.
\end{abstract}

Kata Kunci: Kebijakan, Proses Kebijakan, Partisipasi Masyarakat, Pemberdayaan.

\section{ABSTRACT}

Policy theories in years of 60's era more viewed policy process from public administration perspective. Policy process has been regarded linear and mechanistic. Meanwhile, public participation only viewed as formality by policy legitimation. All this time, participation tends to be interpreted quantitatively-only accounted from participant amount or public organization amount which involved. Even though, policy process will be more meaningful as democracy process when participation expanded the meaning as opportunity to all citizens to deliver the aspiration argumentatively. This article explained how empowering peoples could be doing to participate in the making of policy, that is through by structural approach with advocated any law instruments and institutions that will give the change to people to participated and sociocultural approached by educating process, organizing, and accompaniment.

Keywords: Policy, Policy Process, Public Participation, Empowerment 


\section{PENDAHULUAN}

Teori-teori kebijakan yang berkembang selama dekade 19501980-an memandang proses kebijakan dari perspektif administrasi publik. Dalam perspektif ini, proses kebijakan mulai dari formulasi hingga evaluasi dipandang secara linear layaknya proses yang mekanistis. Karena berada dalam ranah administrasi publik, proses kebijakan dipandang sebagai kewenangan internal pemerintah, sehingga partisipasi masyarakat hanya dipandang sebagai formalitas untuk menambah legitimasi kebijakan tersebut. Idiom black box seringkali digunakan untuk menggambarkan proses legislasi yang berlangsung terbatas dalam ranah suprastruktur merupakan bukti bahwa proses legislasi merupakan proses yang tertutup dari intervensi luar, termasuk masyarakat. Pendekatan semacam itu membawa implikasi negatif karena kebijakan yang dibuat menjadi tidak atau kurang berpihak pada masyarakat.

Oleh karena itu, pandangan tentang studi kebijakan sebagai proses birokratis-administratif yang hanya menjadi domain dari institusi pemerintah menjadi sulit digunakan untuk menjelaskan proses politik yang berlangsung dalam keseluruhan tahap proses kebijakan. Lahirnya suatu produk kebijakan tidaklah otomatis mencapai idealisasinya meskipun telah melalui keseluruhan tahap sebagaimana dikemukakan dalam konsep rasional-komprehensif. Esensi dari ke- bijakan publik sesungguhnya terletak pada hubungan antara negara dan masyarakat. Paradigma kebijakan publik yang kaku dan tidak responsif merupakan cerminan dari hubungan negara dan masyarakat yang kaku dan tidak responsif pula. Sebaliknya, paradigma kebijakan publik yang luwes dan responsif akan merupakan luaran dari hubungan yang luwes dan responsif antara negara dan masyarakat.

Untuk membangun paradigma kebijakan publik yang berorientasi pada aspirasi dan kebutuhan masyarakat, perlu dikembangkan paradigma alternatif yang tidak lagi menempatkan kebijakan publik dalam ranah suprastruktur atau penguasa, tapi sebagai proses interaksi yang seimbang antara suprastruktur dan infrastruktur politik. Proses interaksi yang seimbang ini mensyaratkan adanya ruang-ruang publik yang terbuka bagi partisipasi masyarakat dalam pembuatan kebijakan.

Pada mulanya, pelibatan masyarakat hanya dimungkinkan dalam ruang-ruang di luar ranah suprastruktur dan dilakukan melalui institusi perwakilan, seperti kelompok kepentingan, kelompok penekan, dan partai politik. Institusi-institusi inilah yang kemudian berperan sebagai penyalur aspirasi masyarakat untuk selanjutnya diagregasi oleh parlemen sebagai lembaga perwakilan masyarakat.

Model penyaluran aspirasi semacam itu merupakan karakter khas demokrasi perwakilan. Permasalahan 
kemudian timbul manakala institusiinstitusi perwakilan tersebut lebih berorientasi pada kepentingannya dibandingkan pada kepentingan publik yang diwakilinya. Sistem oligarkhi yang masih mendominasi relasi kekuasaan dalam institusi politik juga menjadi salahsatu penyebab terjadinya distorsi aspirasi karena pihak elitlah yang lebih menentukan aspirasi mana yang akan diperjuangkan, bukan berdasarkan skala prioritas yang obyektif. Alih-alih memperjuangkan aspirasi publik, yang terjadi adalah distorsi aspirasi, sehingga masukan yang bersumber dari masyarakat berbeda dengan kebijakan yang keluar dari proses konversi.

Kendala inilah yang kemudian mendorong perkembangan model demokrasi deliberatif sebagai alternatif untuk meminimalkan potensi distorsi pada pembuatan kebijakan. Di sisi lain, melalui model demokrasi deliberatif, diharapkan ruang-ruang partisipasi bagi publik dapat meluas, karena proses kebijakan dapat berlangsung di luarruang parlemen. Permasalahannya, apakah konsep ini dapat diaplikasikan pada tataran praktik? Di manakah ruang-ruang publik bagi partisipasi dalam pembuatan kebijakan? Apa prasyarat yang harus disiapkan agar perluasan ruang publik benar-benar dapat dimanfaatkan oleh masyarakat untuk menyampaikan aspirasinya?

\section{Proses Kebijakan sebagai Pertarungan Wacana}

Dalam pandangan kritis, studi kebijakan publik sebagai proses politik berkaitan erat dengan konsep demokrasi karena proses kebijakan pada dasarnya berorientasi pada akomodasi kepentingan publik. Kepentingan publik yang dimaksud jelas merupakan proses tarik-menarik dari berbagai kepentingan di masyarakat yang kemudian membentuk opini publik. Dengan demikian, proses kebijakan harus dimaknai sebagai proses dialogis di antara berbagai stakeholders dengan kepentingannya masing-masing yang kemudian hasil kesepakatan dari proses dialog itulah yang akan menentukan isi dari kebijakan tersebut. Dalam banyak kasus, proses dialogis ini seringkali hanya berlangsung di tingkat elit para pengambil keputusan tanpa melibatkan kelompok-kelompok masyarakat lain yang sebenarnya juga terkena dampak dari kebijakan tersebut.

Sebagai proses dialogis, kebijakan dapat dianalisis dari pertarungan wacana dan argumentative turn yang dikemukakan oleh berbagai stakeholders yang terlibat. Pendekatan ini dikemukakan oleh Fischer dan Forester $^{17}$ untuk menganalisis kebijakan sebagai proses praktis dari

17 Lebih lanjut dapat dibaca dalam Peter deLeon. "The Policy Science Redux : New Roads to Postpositivism”. Policy Studies Journal Vol. 22 No. 1. 1994. 
argumentasi. Analisis kebijakan ditekankan pada pengertian-pengertian istilah sosiologis, yaitu karakter retorika dalam konteks spesifik yang meliputi makna dari argumen maupun isu yang dikemukakan.

Proses kebijakan dipandang sebagai kompleksitas kejadian politik yang melibatkan banyak aktor dan banyak kepentingan. Proses kebijakan tidak dipandang sebagai suatu proses yang linier yang dapat dengan mudah diamati dalam rapat-rapat dan pembahasan yang berlangsung dalam ruang parlemen. Sebaliknya, proses kebijakan justru berlangsung melalui lobby, negosiasi, advokasi, pertarungan opini di media massa, bahkan demonstrasi di jalanan. Di sinilah berkembang konsep tentang ruang publik.

Dalam konsepsi ini, ruang publik tidak diartikan secara fisik tetapi merupakan ruang sosial (social space) yang dihasilkan oleh tindakan komunikatif. Ruang publik menjadi tempat bagi terbentuknya opini publik yang merefleksikan isu-isu yang berkembang dalam tataran elit maupun massa ${ }^{18}$. Pembentukan opini publik melalui debat publik akan memiliki kekuatan (communicative power) untuk mempengaruhi pengambilan keputusan yang secara formal dilakukan melalui mekanisme perwakilan. Ketersediaan ruang publik yang terbuka dalam memfasilitasi proses argumentative turn dari pihak parlemen (DPR/DPRD), Pemerintah, maupun kelompok masyarakat yang secara bebas menggunakan berbagai media untuk mengemukakan argumentasinya $^{19}$.

Bentuk-bentuk ruang publik dalam pembuatan kebijakan sangat beragam. Ia dapat berupa pemberitaan di media massa; hearing dengan lembaga legislatif; diskusi di kalangan kelompok-kelompok masyarakat; audiensi dengan lembaga legislatif atau lembaga lain yang berwenang dalam pengambilan keputusan; bahkan jajak pendapat. Dengan demikian, sesungguhnya terdapat peluang yang besar untuk memperluas ruang partisipasi publik dalam pembuatan kebijakan.

Ketersediaan ruang publik yang memfasilitasi pertukaran argumentasi menjadi esensi penting untuk meningkatkan kadar partisipasi publik dalam proses kebijakan. Selama ini,

18 John Dryzek, Deliberative Democracy and Beyond: Liberals, Critics, Contestations. Oxford: Oxford University Press. 2000, hal. 24.

19 Caroline Paskarina. 2005. "Dilema Ruang Publik dalam Demokratisasi”. Artikel dalam Bujet Edisi 07/III/Oktober-November 2005. 
partisipasi cenderung dimaknai secara kuantitatif (hanya dihitung dari jumlah partisipan atau jumlah organisasi masyarakat yang dilibatkan). Padahal, proses kebijakan akan jauh lebih bermakna sebagai proses demokrasi manakala partisipasi diperluas maknanya sebagai kesempatan bagi seluruh warga masyarakat untuk menyampaikan aspirasinya secara argumentatif. Tujuannya, agar aspirasi yang disampaikan dapat mengubah persepsi dari para elit pembuat kebijakan. Transparansi dalam ruang publik juga meminimalkan potensi terjadinya distorsi aspirasi dalam pembuatan kebijakan. Masyarakat dimungkinkan untuk "mengawal" aspirasinya tanpa khawatir "dibajak" oleh elit-elit tertentu.

Perluasan ruang publik juga merupakan bagian dari strategi perubahan kebijakan. Jordan ${ }^{20}$ pernah menggagas sebuah bentuk strategi perubahan kebijakan yang disebut venue change (perubahan tempat kebijakan). Ini adalah strategi perubahan kebijakan dengan cara mengubah fokus kebijakan yang ada pada fokus yang lain, namun masih terkait dengan konteks kebijakan yang ada. Perubahan fokus kebijakan dapat dilakukan dengan melontarkan wacana tandingan (counter discourse) yang memberikan alternatif perspektif dalam memandang suatu isu kebijakan. Misalnya, kebijakan tentang penertiban Pedagang Kaki Lima (PKL) sebenarnya tidak hanya dapat dipandang dari perspektif ketertiban kota, tetapi juga dari perspektif pemberdayaan sektor informal. Ini adalah wacana tandingan yang dapat dimunculkan, sehingga pembuatan kebijakan penertiban PKL perlu mengakomodasi kenyataan sosial bahwa keberadaan PKL ternyata bermanfaat untuk menopang sektor informal dalam perekonomian kota.

Selama ini, protes dan penolakan terhadap suatu kebijakan seringkali timbul akibat ketiadaan wacana tandingan yang memperkaya pertarungan argumen selama proses kebijakan berlangsung. Akibatnya, substansi kebijakan hanya memuat satu atau dua perspektif saja yang umumnya bersumber dari kelompok mayoritas. Padahal, kebijakan publik hakikatnya merupakan suatu bentuk konsensus dari seluruh pihak yang akan terkena dampak dari pemberlakuan kebijakan tersebut. Karena itu, perluasan ruang publik sebagai

20 Dalam Fadillah Putra. 2001. Paradigma Kritis dalam Studi Kebijakan Publik: Perubahan dan Inovasi Kebijakan Publik dan Ruang Partisipasi Masyarakat dalam Proses Kebijakan Publik. Yogyakarta: Pustaka Pelajar, hal. 205. 
wadah pertarungan argumen dalam proses kebijakan menjadi penting untuk menguji validitas klaim yang diajukan pihak-pihak yang terlibat dalam pembuatan kebijakan tersebut, sehingga tidak ada pihak yang mendominasi substansi kebijakan. Inilah makna substantif dari partisipasi masyarakat dalam pembuatan kebijakan.

\section{Peluang Partisipasi dalam Pembuatan Kebijakan}

Pada tataran praktis, peluang partisipasi publik dalam pembuatan kebijakan bisa berada dalam lingkup pembuat keputusan maupun di luar ruang-ruang parlemen. Dalam ranah parlemen, peluang partisipasi berada pada tahap penjaringan aspirasi masyarakat (need assesment). Tahapan ini dilakukan untuk memperoleh data atau informasi dari masyarakat sebagai bahan masukan dalam proses penyusunan kebijakan. Informasi tersebut digunakan untuk menjamin agar kebijakan yang dibuat sesuai dengan aspirasi murni (kebutuhan dan keinginan riil) masyarakat, bukan sekedar aspirasi politik. Pihak-pihak yang terkait dalam penjaringan aspirasi masyarakat adalah ${ }^{21}$ :
1. Parlemen sebagai pemegang wewenang utama dan penyalur semua aspirasi masyarakat yang melaksanakan fungsi legislatif;

2. Perangkat Pemerintah, yang menjalankan fungsi eksekutif;

3. Masyarakat, terdiri atas masyarakat pada umumnya, tokohtokoh masyarakat formal dan informal, Lembaga Swadaya Masyarakat (LSM), asosiasi profesi, perguruan tinggi dan organisasi massa lainnya.

Tugas parlemen pada tahap penjaringan aspirasi masyarakat antara lain:

1. Menjaring aspirasi masyarakat untuk mendapatkan berbagai masukan dan informasi tentang kebutuhan riil melalui metode penjaringan aktif. Bentuk kegiatan berupa: (a) membuat dan menyebarkan kuesioner; (b) melakukan observasi lapangan atau survei untuk mendapatkan aspirasi dan gambaran sesungguhnya yang ada di lapangan; (c) mengadakan dialog interaktif dengan masyarakat secara langsung.

2. Menjaring aspirasi masyarakat untuk mendapatkan berbagai masukan dan informasi tentang kebutuhan riil melalui metode

21 Mardiasmo. Otonomi dan Manajemen Keuangan Daerah. Yogyakarta: Penerbit ANDI. 2002, hal. 127. 
penjaringan pasif. Bentuk kegiatannya dapat dilakukan melalui : (a) pembukaan kotak pos khusus yang dapat menampung surat-surat dari masyarakat dalam menyalurkan aspirasinya; (b) menyediakan kotak saran sebagai tempat masyarakat menyampaikan aspirasinya; (c) membuat web site khusus dengan fasilitas penerima email dari masyarakat; (d) menyediakan telepon bebas pulsa untuk menerima aspirasi masyarakat melalui line telepon.

3. Menjaring aspirasi masyarakat secara reaktif untuk mendapatkan berbagai masukan dan informasi tentang kebutuhan riil masyarakat. Bentuk kegiatannya berupa: (a) public hearing; (b) kegiatan inspeksi mendadak (sidak).

4. Merumuskan hasil penjaringan masyarakat tersebut ke dalam sebuah dokumen aspirasi yang memuat aspirasi dan kebutuhan riil masyarakat.

Masyarakat dapat menyampaikan aspirasinya melalui sejumlah saluran yang tersedia, baik di DPR, DPD maupun DPRD di tingkat daerah, sebagaimana termuat pada Tabel 1 berikut ini. Pilihan untuk menentukan kepada badan mana gagasan kita ingin disampaikan, sebenarnya tergantung pada rancangan kebijakan yang akan atau sedang dibuat. Misalnya, untuk RUU/Raperda yang sudah masuk tahap pembahasan, akan lebih efektif apabila gagasan disampaikan kepada anggota DPR/DPD/DPRD yang membahas RUU/Raperda tersebut. Namun gagasan pada tahap awal, misalnya topik RUU/Raperda tertentu atau Rancangan Akademik RUU/ Raperda atau naskah RUU/Raperda tertentu, bisa lebih luas diwacanakan, termasuk melalui media massa.

Tabel 1

Mekanisme Penyampaian Aspirasi dalam Pembuatan Kebijakan

\begin{tabular}{|c|c|c|c|c|}
\hline No. & Item & DPR & DPD & DPRD \\
\hline & $\begin{array}{l}\text { Kepada siapa } \\
\text { aspirasi } \\
\text { disampaikan? }\end{array}$ & $\begin{array}{ll}\text { 1. } & \begin{array}{l}\text { Anggota DPR } \\
\text { dari Komisi atau } \\
\text { Pansus atau Panja } \\
\text { yang membahas }\end{array} \\
\text { RUU } \\
\text { 2. }\end{array}$ & 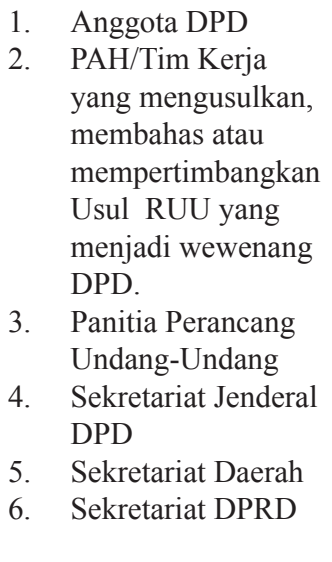 & $\begin{array}{ll}\text { 1. } & \text { Anggota DPRD } \\
\text { 2. } & \text { Badan Legislasi } \\
& \text { DPRD } \\
\text { 3. } & \text { Fraksi-fraksi } \\
& \text { DPRD } \\
\text { 4. } & \text { Sekretariat DPRD }\end{array}$ \\
\hline
\end{tabular}




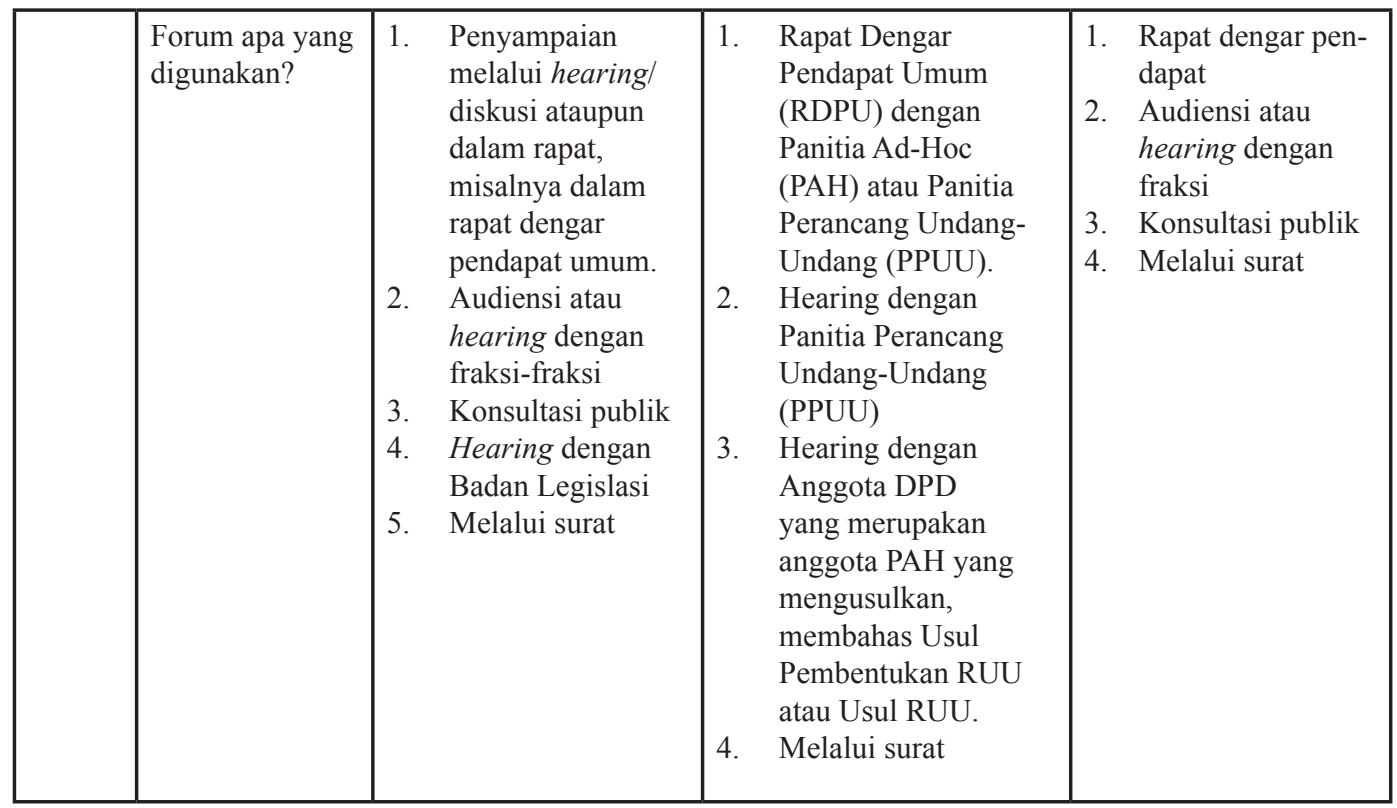

Sumber: www.parlemen.net

Ditinjau dari sisi forum atau media yang dapat digunakan, terdapat beragam mekanisme yang tersedia meski cenderung bersifat formal dan limitatif. Hal ini memang menjadi salahsatu kelemahan dari model perwakilan yang selama ini diterapkan. Mereka yang diundang dalam pembahasan rancangan kebijakan biasanya yang tergabung dalam suatu kelompok kepentingan atau kelompok penekan, sehingga bias kepentingan mungkin saja terjadi dalam artikulasi dan agregasi kepentingan. Berbagai aturan protokoler selama pembahasan dalam parlemen juga dapat menjadi kendala yang membatasi peluang partisipasi bagi kelompok masyarakat yang termarginalkan, misalnya masya- rakat miskin, komunitas adat, dll. Karena itu, terdapat sejumlah kiat yang perlu diperhatikan manakala kita memanfaatkan mekanisme formal ini dalam menyalurkan aspirasi. Kiat-kiat tersebut adalah ${ }^{22}$ :

1. Rapat Dengar Pendapat Umum (RDPU)

Forum ini adalah forum resmi yang ada dalam proses pembahasan sebuah kebijakan (RUU atau Raperda). Forum ini diadakan pada saat pembahasan tingkat I RUU/Raperda, yaitu setelah adanya pemandangan umum fraksi atas RUU/Raperda atau pemandangan umum pemerintah atas RUU/Raperda dari DPR/DPRD.

22 Download dari www.parlemen.net, 11 Oktober 2006. 
Untuk dapat terlibat dalam forum ini, cara-cara yang harus kita tempuh adalah:

- Identifikasi terlebih dahulu, sudah sampai tingkat mana pembahasan RUU/Raperda.

- Kirimkan surat kepada ke Sekretariat Komisi/Pansus yang membahas RUU/ Raperda.

- Sebutkan maksud dan tujuan untuk meminta adanya RDPU tersebut.

- Pastikan kita memiliki bahan yang siap dibagikan dalam RDPU tersebut, agar pembahasannya bisa fokus.

- Pantau terus perkembangan dari gagasan kita dalam pembahasan-pembahasan selanjutnya.

2. Audiensi atau hearing dengan fraksi-fraksi

Forum ini lebih fleksibel, artinya tidak ada waktu yang terjadwalkan sehingga kita dapat melakukan kapan saja sepanjang proses pembahasan RUU/Raperda itu berlangsung. Sulitnya, penjadwalan dan kesediaan fraksi untuk bertemu dengan kita sepenuhnya tergantung pada kemauan fraksi tersebut. Namun, hal ini bisa diatasi dengan menyampaikan surat permohonan dengan maksud, tujuan, serta identifikasi institusi/individu yang jelas, dan ditindaklanjuti melalui hubungan telepon secara intensif.
Hearing dengan fraksi dapat lebih mudah jika kita mengenal salahsatu anggota dari fraksi yang bersangkutan. Kalaupun tidak, kita dapat memintanya ke sekretariat fraksi. Tentukan alasan serta tawaran waktu untuk bertemu untuk memudahkan fraksi/sekretariat fraksi menyusun jadwal. Jangan lupa cantumkan identifikasi institusi/individu dengan jelas serta nomor telepon yang dapat dihubungi agar komunikasi penentuan jadwal dapat lebih mudah terjadi.

3. Konsultasi Publik

DPR/DPRD kadang-kadang melakukan mekanisme konsultasi publik (sosialisasi) untuk RUU/ Raperda banyak mendapatkan sorotan. Konsultasi publik (sosialisasi) bisaanya dilakukan di beberapa kota besar. Untuk berpartisipasi, cara-caranya sebagai berikut:

- Mintalah informasi kepada sekretariat Komisi/Pansus mengenai kapan dan di mana saja konsultasi publik akan diadakan, serta organisasi yang menjadi mitra lokal DPR/DPRD.

- Jika kota anda termasuk yang akan dikunjungi, mintalah kepada penyelenggara lokal untuk mengundang anda dalam forum tersebut.

- Jika informasi tentang mitra lokal tidak juga didapatkan, anda dapat menghubungi 
pemerintah daerah setempat ataupun universitas negeri di kota anda, karena Sekretariat DPR/DPRD biasanya bekerja sama dengan pemerintah daerah atau dengan perguruan tinggi di kota tersebut.

- Datanglah dengan membawa usulan secara tertulis. Selain mempermudah untuk dipelajari, juga berjagajaga jika anda tidak sempat menyampaikan usulan secara lisan/langsung dalam forum tersebut.

- Mintalah hasil konsultasi publik tersebut dan pantaulah perkembangan usulan anda di pembahasan RUU/Raperda tersebut selanjutnya.

4. Hearing dengan Badan Legislasi Badan Legislasi DPR/DPRD saat ini menjadi badan yang cukup berpengaruh dalam proses legislasi DPR/DPRD. Ada beberapa hal yang bisa dilakukan dengan Badan Legislasi DPR, yakni:

- Memasukkan naskah usulan anda untuk dijadikan RUU/ Raperda usul inisiatif DPR/ DPRD.

- Memberikan masukan atas suatu naskah RUU/Raperda yang sedang dibahas.

5. Melalui surat

Setiap waktu masyarakat dapat mengirimkan saran, kritik dan masukan kepada anggota DPR/
DPD/DPRD melalui Sekretariat Daerah dan Sekretariat DPRD di daerah masing-masing. Semua masukan dan kritikan akan disampaikan kepada anggota DPR/DPD/DPRD pada saat kunjungan kerja.

Caranya dengan mengirimkan surat langsung yang dapat berisi usulan RUU/Raperda, pertimbangan atas suatu RUU/ Raperda yang berada dalam lingkup kewenangan DPR/DPD/ DPRD kepada Sekretariat Daerah atau Sekretariat DPRD.

Selain yang bersumber dari inisiatif masyarakat untuk menyampaikan aspirasi, anggota legislatif pun sebenarnya memiliki peran besar untuk menjaring aspirasi masyarakat. Waktu reses dapat digunakan untuk menjalin hubungan dengan masyarakat dan konstituen pada khususnya, termasuk untuk menggali aspirasi dan kebutuhan masyarakat. Namun, pemanfaatan masa reses ini akan lebih efektif bila ada instrumen penjaringan aspirasi yang jelas yang dapat digunakan sebagai panduan oleh anggota legislatif untuk mengidentifikasi aspirasi dan kebutuhan masyarakat. Metode analisis stakeholders, analisis skala prioritas kebutuhan masyarakat, penyelenggaraan focus group discussion (FGD), atau pengumpulan (kliping) berita media lokal merupakan contoh metode penjaringan aspirasi yang dapat diterapkan oleh anggota legislatif. Melalui metode ini, anggota legislatif dapat memperoleh masukan 
yang obyektif mengenai kebutuhan riil masyarakat, sehingga memiliki posisi tawar (bargaining position) yang kuat ketika bernegosiasi dengan eksekutif dalam proses pembuatan kebijakan, termasuk ketika membahas alokasi APBD.

Ketersediaan ruang publik juga dapat dimaknai sebagai proses advokasi terhadap materi kebijakan. Advokasi kebijakan publik merupakan salahsatu pendekatan yang dapat digunakan untuk memfasilitasi partisipasi masyarakat dalam pembuatan kebijakan publik. Pendekatan advokasi dalam pembuatan kebijakan publik diperlukan agar kebijakan betul-betul memihak pada kepentingan masyarakat. Selain itu, ada juga perubahan konteks penyelenggaraan pemerintahan yang menempatkan advokasi kebijakan menjadi penting, yakni adanya pergeseran paradigma model advokasi dari litigasi (penyelesaian di pengadilan) menjadi legislasi. Model advokasi yang berupa litigasi terutama berada dalam konteks negara yang dominan dan otoriter yang tidak memberikan ruang bagi partisipasi masyarakat. Sementara dalam konteks sekarang, di mana ruang partisipasi masyarakat sudah terbuka luas, maka model advokasi dapat diarahkan untuk merubah kebijakan publik.
Secara konseptual, advokasi kebijakan menyangkut ekspresi keberpihakan seseorang pada nilainilai tertentu. Dari perspektif populis, tentu saja nilai-nilai yang ingin diperjuangkan adalah nilai-nilai yang berpihak pada kepentingan masyarakat. Dengan demikian, advokasi kebijakan dalam perubahan kebijakan publik tidak hanya cukup sampai mengubah isi keputusan pemerintah, namun juga mengubah kondisi yang dikehendaki dengan cara memastikan penentu kebijakan berada di pihak yang melakukan advokasi. Karena itulah, advokasi harus dilakukan dalam setiap tahap proses kebijakan. Ketika advokasi kebijakan dipahami sebagai kerangka kerja dalam proses kebijakan dan bukan sekedar penggalangan kekuatan untuk mengubah isi kebijakan yang telah dibuat pemerintah, maka perubahan kebijakan tidak sekedar menjadi fenomena yang sporadis dan temporer. Advokasi kebijakan dapat menjadi sarana untuk mengembangkan partisipasi masyarakat, mengubah karakter pengambil kebijakan, dan pada akhirnya mengadakan perubahan politik di tingkat lokal.

Pada praktiknya, advokasi kebijakan dapat dilakukan melalui beragam strategi, seperti tergambar dalam alur di bawah ini. 
Gambar 1

Jalur Advokasi Kebijakan

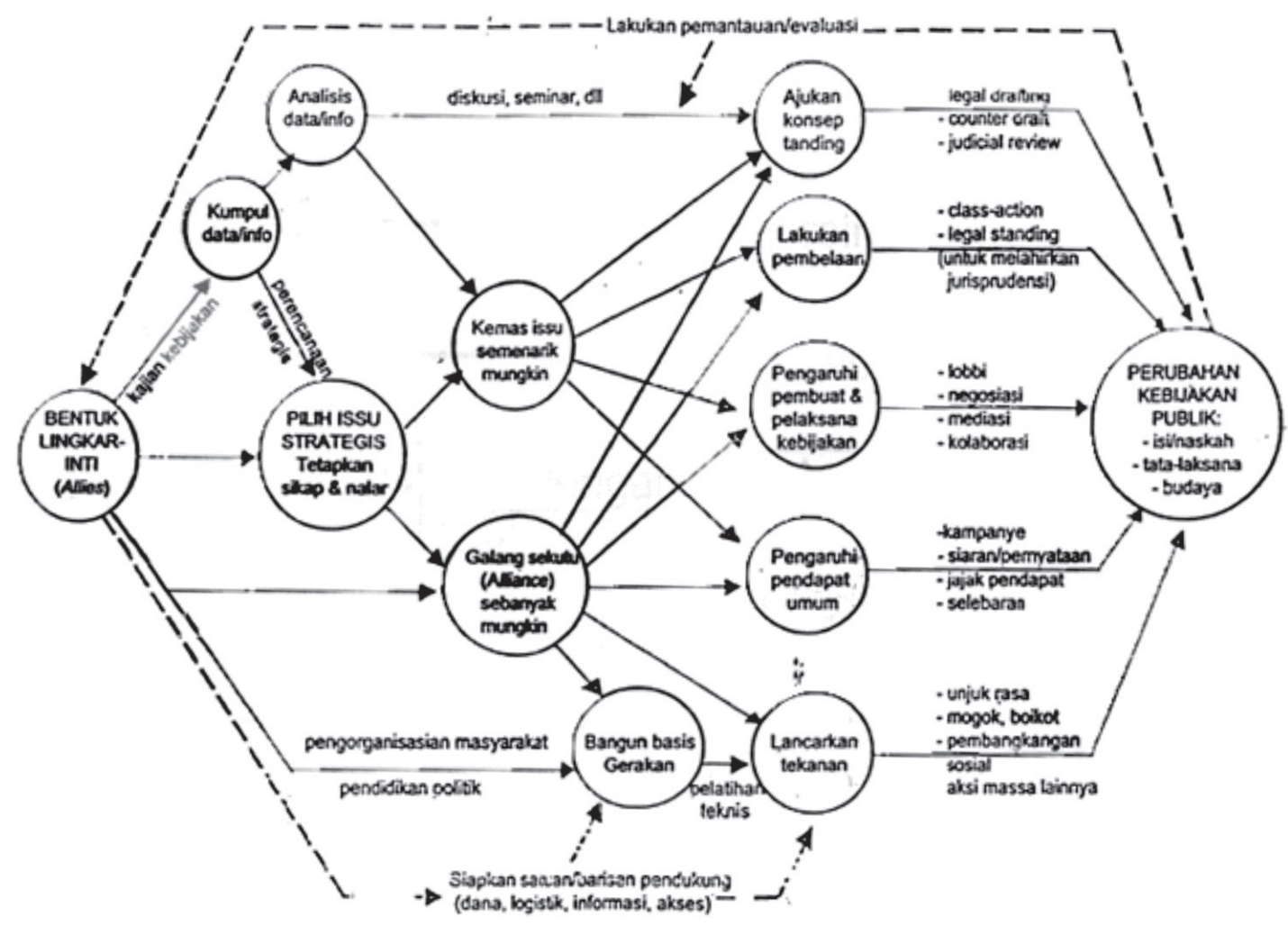

Sumber: Mansour Fakih, dkk., 2000.

Dalam gambar di atas, tampak bahwa jalur advokasi kebijakan dapat dilakukan baik dengan menggunakan otak maupun otot, mulai dari teknik legal drafting, pengembangan jejaring kemitraan, lobby dan negosiasi hingga menggunakan cara-cara non konvensional seperti unjuk rasa, mogok, boikot, dan aksi massa lainnya. Namun, prinsipnya baik upaya penyampaian aspirasi maupun advokasi kebijakan harus senantiasa dilakukan dalam kerangka normatif sesuai dengan peraturan perundangundangan yang berlaku. Hal ini diperlukan sebagai strategi untuk menarik simpati dan dukungan masyarakat.

\section{Prasyarat Pemanfaatan Ruang Publik}

Perluasan ruang publik tentu saja tidak dapat dipahami sebagai proses yang netral karena di dalamnya akan selalu ada beragam kepentingan, baik dari level elit maupun massa. Terlepas dari kekurangan-kekurangan yang masih terdapat dalam proses deliberasi, kemunculan ruang publik yang difasilitasi oleh media massa, akademisi, dan LSM membawa dampak positif bagi pembelajaran 
politik publik. Agar ketersediaan ruang publik menjadi efektif, maka prasyarat utama yang diperlukan adalah pemberdayaan masyarakat.

Perluasan ruang publik berkaitan erat dengan kemampuan seluruh elemen masyarakat untuk memproduksi wacana tandingan untuk melawan hegemoni wacana utama ${ }^{23}$. Wacana tandingan tidak akan dapat terbentuk bila pertarungan wacana berlangsung secara tidak seimbang di mana penguasa menentukan bagaimana suatu isu dibentuk, didefinisikan, dan dipublikasikan. Proses deliberasi ini rentan dengan dominasi elit karena hanya kelompok elitlah yang memiliki akses untuk membentuk, mendefinisikan, dan mempublikasikan isu-isu.

Oleh karena itu, pemberdayaan masyarakat diorientasikan pada upaya memperkuat kemampuan masyarakat dalam memaknai dan memahami wacana yang berkembang, termasuk isu-isu yang menjadi agenda kebijakan publik. Meningkatnya pemahaman masyarakat akan memperkuat posisi tawar masyarakat berhadapan dengan negara, sehingga relasi kekuasaan menjadi lebih seimbang, termasuk dalam proses kebijakan. Ada dua pendekatan yang dapat dilakukan untuk memberdayakan masyarakat, yakni: pertama, pendekatan struktural. Pendekatan struktural dilakukan dengan cara mengadvokasikan berbagai instrumen hukum dan kelembagaan yang memberi peluang bagi masyarakat untuk berpartisipasi, mengakses informasi, dan mengontrol akuntabilitas pemerintahan. Instrumen hukum yang sangat penting untuk menjamin partisipasi dan akuntabilitas adalah undang-undang/peraturan daerah mengenai partisipasi masyarakat dan undang-undang/peraturan daerah mengenai hak warga untuk mendapatkan informasi. Sedangkan instrumen kelembagaan yang penting adalah penumbuhan organisasi lokal dan fungsional yang dapat menampung aspirasi dan menyalurkan kepentingan masyarakat lokal/fungsional sebagai konstituennya. Dengan mengoptimalkan kedua instrumen ini maka kemungkinan terjadinya dominasi wacana dapat dihindari.

Kedua, pendekatan sosiokultural. Pendekatan ini dilakukan melalui proses pendidikan, pengorganisasian, dan pendampingan masyarakat agar masyarakat dapat mengindentifikasi dan mengartikulasi aspirasi dan kepentingan mereka, sehingga potensi manipulasi aspirasi dan kepentingan masyarakat dapat diminimalkan. Pen-

23 Caroline Paskarina. 2004. Ruang Publik dalam Pemilihan Walikota Bandung Tahun 2003. Tesis Program Pascasarjana Ilmu Politik Konsentrasi Politik Lokal dan Otonomi Daerah Universitas Gadjah Mada Yogyakarta (tidak dipublikasikan). 
dampingan masyarakat oleh kelompok-kelompok swadaya masyarakat atau akademisi juga dapat dilakukan untuk memfasilitasi masyarakat dalam merumuskan dan menyampaikan konsep-konsep alternatif yang membekali masyarakat untuk berpartisipasi dalam merumuskan ulang kebijakan.

Dengan demikian, proses kebijakan dapat dipahami sebagai proses pertarungan wacana antara pihakpihak yang berkepentingan. Proses formulasi kebijakan tidak hanya mencakup negosiasi antar elit dalam arena DPR/DPRD karena ternyata wacana dan perdebatan yang berkembang di tingkat publik dapat menarik keluar proses pembahasan tersebut ke dalam ruang publik dan pada akhirnya publik dapat mendesakkan masuknya kepentingan publik yang lebih rasional ke dalam kebijakan tersebut. Inilah hakikat dari dinamika politik masyarakat dalam suatu proses kebijakan.

\section{DAFTAR PUSTAKA}

deLeon, Peter. (1994). "The Policy Science Redux: New Roads to Postpositivism". Policy Studies Journal Vol. 22 No. 1.
Dryzek, John. (2000). Deliberative Democracy and Beyond: Liberals, Critics, Contestations. Oxford: Oxford University Press.

Fakih, Mansour, Roem Topatimasang, dan Rahardjo (eds). (2000). Merubah Kebijakan Publik. Yogyakarta: Pustaka Pelajar.

Mardiasmo. (2002). Otonomi dan Manajemen Keuangan Daerah. Yogyakarta: Penerbit ANDI.

Paskarina, Caroline. (2004). Ruang Publik dalam Pemilihan Walikota Bandung Tahun 2003. Tesis Program Pascasarjana Ilmu Politik Konsentrasi Politik Lokal dan Otonomi Daerah Universitas Gadjah Mada Yogyakarta (tidak dipublikasikan).

. (2005). "Dilema Ruang Publik dalam Demokratisasi". Artikel dalam Bujet Edisi 07/III/OktoberNovember 2005.

Putra, Fadillah. (2001). Paradigma Kritis dalam Studi Kebijakan Publik: Perubahan dan Inovasi Kebijakan Publik dan Ruang Partisipasi Masyarakat dalam Proses Kebijakan Publik. Yogyakarta: Pustaka Pelajar. www.parlemen.ne 